\title{
Customer Satisfaction on Online Shopping at Covid-19 Pandemic in Medan
}

\author{
Sahala Siallagan \\ \{sahalaall@unimed.ac.id\} \\ Mechanical Engineering Education Department, Faculty of Engineering, Universitas Negeri Medan \\ Jl. Willem Iskandar, Pasar V, Medan, Indonesia
}

\begin{abstract}
The Corona-19 Pandemic, greatly affected the socio-economic of the community by restrictions on daily activities. Restrictions, such as social distancing, physical distancing makes the economic situation more difficult. This situation has resulted in a reduction of workforce and even layoffs in many sectors. Due to the daily needs, many people have to do trading by relying on information technology (IT), namely trading online.This study aims to describe the customer satisfaction on online shopping during the Corona-19 Pandemic. Doubtedly many online sellers have sprung up by perforce due to increasingly difficult economic conditions, which are believed to have neither managerial capabilities nor satisfactory service.The population of this study is the students at the universities in Medan. Judgment sampling was used in this research. The type of research is a qualitative descriptive study to describe. The results of the study indicates that customer satisfaction in low category.
\end{abstract}

Keywords: customer satisfaction, online shopping, covid-19.

\section{Introduction}

The advancement of information technology and the internet has benefited the Indonesian people. Technology and the internet have the ability to modernize the lifestyles of those who have previously been left behind. Making it easier to find information, communicate, work, and so on are some of the beneficial effects of developing technology and the internet in Indonesia. Indonesia had roughly 175.5 million internet users in 2020, out of a total population of $268,583,016$ people, with a national digital penetration of 64 percent in all areas. When compared to the previous year in 2019, the number of internet users in 2020 climbed by 25 million (17\%). This service is used by the majority of internet users to access social media, chat applications, banking, entertainment, and online shopping [1].

In online marketing, an online customer service system has become a crucial tool. Realtime online consumer services are becoming more common as information technology (IT) develops at a rapid pace. Online shopping is based on the internet since it allows users to accomplish a variety of things, including communicate with people all over the world online. Online shopping is a new way to conduct business. Buyers and sellers do not meet face-toface in this activity, as they would in a conventional sales procedure. Consumers are drawn to internet purchasing because of the efficiency and effectiveness of the transaction procedure. Sellers will use the internet to present their site as a storefront, complete with all of the things available to customers. Then, as purchasers, they will see and decide to purchase the things 
presented on the existing site. The growing number of internet users each year may open up opportunities for online buying and selling. E-commerce can be applied to conduct transactions such as selling, buying, and promoting things through the internet. The following are some of the benefits of implementing online transactions for a business: 1) generating revenue by lowering costs such as postage and printing; 2) decreasing delays by utilizing electronic technology

The Covid-19 has had an impact on all activities, particularly those related to basic human necessities. Layoffs cause many workers to lose their jobs. Because of the pandemic, everyone must be resourceful in order to survive. The ease with which information communication technology (ICT) allows you to start a trading firm without needing a huge amount of capital or the usage of a shop. Communication technology gadgets are used to conduct business. The communication technology equipment is all that is required for an internet enterprise. This circumstance is also a challenge difficulty for entrepreneurs who have traditionally operated their businesses. These online traders are thought to lack managerial skills to run a successful firm. Currently, there are a number of online stores that place a lower priority on client satisfaction. Many of them desire a high number of clients while ignoring customer satisfaction. Client happiness is a valuable asset for online purchasing since it can increase customer trust and loyalty. The term "customer satisfaction" refers to a comparison of expectations and actual results.

\section{Method}

The Online shopping is a type of electronic commerce that allows customers to buy goods or services directly from sellers over the Internet via a web browser or a mobile app. Consumers find a product of interest by going straight to the retailer's website or by utilizing a shopping search engine to compare the availability and pricing of similar products from different vendors. Customers are able to shop online using a variety of computers and devices by 2020 , including desktop computers, laptops, tablets, and smartphones. Shoppers may frequently utilize search features to find certain models, brands, or items in online stores. To conduct an online transaction, users must have Internet access and a legitimate mode of payment, such as a credit card, an Interac-enabled debit card, or a service like PayPal. For physical products (e.g., paperback books or clothes), the e-tailer ships the products to the customer; for digital products, such as digital audio files of songs or software, the e-tailer usually sends the file to the customer over the Internet.

Customer satisfaction is described as a metric that determines how well a company's products or services meet the needs of its customers. One of the most important measures of consumer purchase intentions and loyalty is customer satisfaction. Customer satisfaction is a metric used to assess how satisfied customers are with a company's goods, services, and capabilities. Information on customer satisfaction, such as surveys and ratings, can aid a firm in determining how to enhance or adjust its products and services. Customer happiness is critical and should not be overlooked. Customer satisfaction is one of the many aspects that contribute to the success (or failure) of a firm. It's critical to keep track of this characteristic and seek to improve it if you want to increase client loyalty and turn them into brand ambassadors. Customer happiness is particularly important, according to Deng [2], because it is linked to the customer's loyalty and willingness to repurchase. Security, information quality, 
payment method, virtual service quality, product quality, product range, and service provision are some of the determinants of customer happiness [3].

High-standard customer service can win the clients' hearts and make recognizable within target market. Nowadays when social media play such an important role in making decisions it's crucial to keep an eye on the quality of customer service provided. If online sellers don't care about customers' satisfaction, they cannot expect customers to care about the services or products given. Some research says that it is 6-7 times more expensive to acquire a new customer than it is to keep a current one. On average, loyal customers are worth up to 10 times as much as their first purchase. Furthermore, Syed Shah Alam [4] argue that customer satisfaction is the result of a customer's observation of the value received from the product or service what is expected.

The study's participants are students from Medan's Universities, and it is presumed that they commonly purchase items from internet stores. They are: 1) Universitas Sumatera Utara, 2) Universitas Negeri Medan, 3) Universitas Islam Negeri, 4) Universitas Islam Sumatera Utara, 5) Universitas Muhammadyah Sumatera Utara, 6) Universitas Katolik (UNIKA), 7) Universitas HKBP Nomennensen, 8) Universitas Darma Agung, 9) Universitas Prima, 10) Universitas Alwaslyah. In this study, a certain amount of judgment is used in the use of purposive sampling. Questionnaires are provided to ten students from each university who are Medan natives, resulting in a total sample size of 100 students. The questionnaires were distributed to the first ten students, who were given time to complete them before being interviewed for a brief time. In this study, the qualitative descriptive method is used. Likert scale survey questions are used to gauge respondent satisfaction, such as: strongly agree $=5$, agree $=4$, Neutral $=3$, disagree $=2$, strongly disagree $=1$.

\section{Results and Discussion}

Table 1. Descriptive analysis of customer satisfaction.

\begin{tabular}{|c|c|c|c|c|c|c|c|c|}
\hline No & Indicator & SA & A & $\mathrm{N}$ & $\mathrm{D}$ & SD & Mean & $\begin{array}{l}\text { Std. } \\
\text { Dev. }\end{array}$ \\
\hline & INFORMATION QUALITY & & & & & & & \\
\hline 1 & Offered product same as received & - & - & - & 40 & 60 & 1.400 & .490 \\
\hline 2 & Promised promotion is kept & - & - & - & 55 & 45 & 1.550 & .497 \\
\hline 3 & $\begin{array}{l}\text { Informed products are available } \\
\text { PAYMENT METHOD }\end{array}$ & - & - & - & 55 & 45 & 1.550 & .497 \\
\hline 4 & e-banking can be used & - & - & - & 55 & 45 & 1.550 & .497 \\
\hline 5 & $\begin{array}{l}\text { Products purchased according to } \\
\text { payment }\end{array}$ & - & - & - & 40 & 60 & 1.400 & .490 \\
\hline 6 & $\begin{array}{l}\text { Cash on delivery is accepted } \\
\text { VIRTUAL QUALITY SERVICE }\end{array}$ & - & 5 & 5 & 60 & 30 & 1.850 & .726 \\
\hline 7 & Online sellers serve requests well & - & 15 & 50 & 30 & 5 & 2.750 & .766 \\
\hline 8 & $\begin{array}{l}\text { Online sellers response any } \\
\text { complaints }\end{array}$ & - & 5 & - & 65 & 30 & 1.800 & 678 \\
\hline 9 & $\begin{array}{l}\text { Bargaining is response patiently } \\
\text { PRODUCT QUALITY }\end{array}$ & 5 & 10 & 35 & 25 & 25 & 2.450 & 1.117 \\
\hline 10 & Product ordered is same as received & 5 & - & 80 & 10 & 5 & 3.850 & .572 \\
\hline 11 & $\begin{array}{l}\text { Product offered same as at the } \\
\text { market place }\end{array}$ & 25 & 40 & 25 & 5 & 5 & 3.750 & 1.043 \\
\hline
\end{tabular}




\begin{tabular}{|c|c|c|c|c|c|c|c|c|}
\hline 12 & $\begin{array}{l}\text { Quality of product compatible to } \\
\text { the price } \\
\text { PRODUCT RANGE }\end{array}$ & - & 5 & 5 & 70 & 15 & 2.000 & .649 \\
\hline 13 & $\begin{array}{l}\text { Various product eventhough same } \\
\text { manufacturer }\end{array}$ & - & 5 & - & 75 & 20 & 1.900 & .624 \\
\hline 14 & $\begin{array}{l}\text { The products offered cover the ages } \\
\text { of teenagers to old people }\end{array}$ & - & - & 5 & 55 & 40 & 1.650 & .572 \\
\hline 15 & $\begin{array}{l}\text { All the products sold are daily used } \\
\text { SERVICE PROVISION }\end{array}$ & - & - & - & 45 & 55 & 1.450 & .497 \\
\hline 16 & $\begin{array}{l}\text { When buying a promo price } \\
\text { product, the service is maintained }\end{array}$ & - & - & - & 50 & 50 & 1.500 & .500 \\
\hline 17 & $\begin{array}{l}\text { Eventhough many order, the service } \\
\text { is maintined }\end{array}$ & - & - & - & 55 & 45 & 1.550 & .497 \\
\hline 18 & Goods delivered according to order & 5 & 10 & 55 & 15 & 15 & 2.750 & .994 \\
\hline
\end{tabular}

Table 1 shows the decriptive analysis of customer satisfaction. When it comes to delivering any product-related news to customers, information quality is critical. By employing information, internet sellers can establish trust with their customers. Buyers, on the other hand, will be dissatisfied if online suppliers fail to deliver on their promises. According to respondents, the information provided does not correspond to reality. Electronic banking, such as online banking and sms banking, will make transactions more convenient, especially during the Covid-19 pandemic. The buyers in this survey don't do it. Paying before accepting things is generally not a good idea. One of the capitals of sellers is providing excellent service in order to attract and retain more clients. It is easier to gain new customers than it is to keep existing ones. The majority of respondents were dissatisfied with the sellers' service and response. Customers who are dissatisfied are thought to be disloyal. The majority of clients are dissatisfied with the things they receive since they are not as ordered and the product quality is not commensurate with the price. However, the products on offer are identical to those found on the market. Buyers have few options because the products available are limited in variety and do not cater to all ages. Furthermore, none of the products sold are utilized on a regular basis. Almost all consumers concede that service is unsatisfactory, yet half of them admit that the things provided are as ordered.

There are 18 questions in total, with six different classes. The maximum score is $18 \times 5$, which equals 90, and the lowest score is $18 \times 1$, which is 18 . Standard deviation ideal (SDi) = highest score - lowest score $=90-18=72$; Mean ideal (Mi) is the sum of the highest and lowest scores, which is $90+18=108$. According to the questionnaire, all of the study's samples fall into the low customer satisfaction group, as indicated in Table 2 below.

Table 2. Category of customer satisfaction.

\begin{tabular}{|c|c|c|c|}
\hline & & Category & Sample \\
\hline$>\mathrm{Mi}+1.5 \mathrm{SDi}$ & $>216$ & very high & - \\
\hline$(\mathrm{Mi}+0.5 \mathrm{SDi})-(\mathrm{Mi}+1.5 \mathrm{SDi})$ & $144-216$ & high & - \\
\hline$(\mathrm{Mi}-0.5 \mathrm{SDi})-(\mathrm{Mi}+0.5 \mathrm{SDi})$ & $72-144$ & moderate & - \\
\hline$(\mathrm{Mi}-1.5 \mathrm{SDi})-(\mathrm{Mi}-0.5 \mathrm{SDi})$ & $0-72$ & low & 100 \\
\hline$<\mathrm{Mi}-1.5 \mathrm{SDi}$ & $<0$ & very low & - \\
\hline
\end{tabular}

Source: Hopkins \& Antes, 1978. 


\section{Conclusion}

Even before encouraging to stay at home to prevent the spread of a virus, online shopping was convenient. Indonesian online shopping websites are not only easy, but also important now that the people should be staying inside as much as possible. Satisfaction and devotion aren't enough to keep a company alive; a management site is also necessary to support online sellers. For satisfied customers to refer to others, communication by word of mouth will be very valuable. Unsatisfied buyers, on the other hand, not only do not refer to future consumers, but also exacerbate the situation. The online shops need to improve management, quality service, and communication in order to survive the business especially during the covid-19 pandemic. It should not just a trial and error method but based on scienctific method to avoid the failure of online business. To stay in business, online stores must enhance management, customer service, and communication, especially during the covid-19 pandemic. To avoid online company failure, it should not merely be a trial and error process, but rather a scientific method.

Acknowledgments. Author would like to thank to LPPM UNIMED for funding this research.

\section{References}

[1] Republika.co.id. Kominfo: Pengguna Internet Indonesia Terbesar Ke-4 di Dunia. Available from: https://www.republika.co.id/berita/qv56gb335/kominfo-pengguna-internet-indonesia-terbesar-ke4di-dunia [Accessed $14^{\text {th }}$ July 2021].

[2] Deng Z, Lu Y, Wei KK, Zhang J. Understanding customer satisfaction and loyalty: An empirical study of mobile instant messages in China. Int J of Infor Man. 2010; 30(4):289-300.

[3] Vasić N, Kilibarda M, Kaurin T. The influence of online shopping determinants on customer satisfaction in the Serbian market. J of theo and app elec com. res. 2019; 14(2):70-89.

[4] Alam SS, Ali MH, Omar NA, Hussain WMHW. Customer satisfaction in Online Shopping in Growing Markets: An Empirical Study. Int J of Asian Bus. and Inf Man. 2020; 11(1):78-91. 